\title{
AERATION OF HIGH MOISTURE ROUGH RICE USING NATURAL AND COOLED AIR
}

\author{
EL-KHOLY, M. M and G. K. ARAFA
}

Agr. Eng. Res. Inst., ARC, Dokki, Giza, Egypt.

(Manuscript received 12 April 2016)

\begin{abstract}
$\Lambda$ study was carried out during to evaluate the effectiveness of different aeration methods on keeping quality of freshly harvested rough rice during short term storage. Two different aeration methods were evaluated using two different types of air (natural and cooled air), and three different air flow rates, $(0.02,0.04$ and $.06 \mathrm{~m}^{3} / \mathrm{h} . \mathrm{kg}$.). Seven lots of high moisture rough rice each of $25 \mathrm{~kg}$ were stored in laboratory scale metal silos for 15 days. Three lots aerated with natural air, three lots aerated with cooled air, and one lot was left without aeration as control. The effect of aeration methods on grain final quality was evaluated in terms of grain final moisture content, milling effectiveness, fungal growth rate and grain discoloration. The results show that, dry cooled air used for cooled aeration, reduced the grain moisture content to a range of 14.52 to $16.93 \%$ w.b. as compared to 17.19 to $18.96 \%$ w.d. for natural aeration. The ranges of air temperature and relative humidity used for aeration process were 11.01 to $13.92{ }^{\circ} \mathrm{C}$ and 38.79 to $43.72 \%$ for refrigerated air respectively compared to 27.26 to $29.76{ }^{\circ} \mathrm{C}$ and 68.53 to $76.15 \%$ for natural air respectively. The lower air temperature and relative humidity used for cooled aeration reduced the grain moisture content and temperature to a levels prevented spoilage and preserved the grain final quality as compared to natural aeration.
\end{abstract}

\section{INTRODUCTION}

The advantages of proper storage include gaining a high percentage of head rice yield, improving overall quality, and maximizing the selling price. Poor storage reduces the quantity of available paddy and dilutes the quality. Improper storage of bulk paddy under high temperature and high relative humidity conditions is risky in that it promotes rapid deterioration. Heat accumulates inside the paddy bulk and accelerates the loss of quality. If the rice kernal is stored in a high humidity environment. It will absorb moisture. As a result increasing of its breathing which produces heat that accumulates in the bulk paddy and ultimately promotes unwanted microbial growth and discoloration (Zhou et al., 2002). It is well known that low temperatures are desirable for the better preservation of seeds and grain quality. Although the role of temperature has long been recognized as an important regulator 
of biological process. Manipulation of this regulator by means of aeration techniques was only brought into focus in the early of 1959. Aeration is very often applied in the storage of just-harvested damp grain before being dried especially where local drying capacity insufficient (Chang et. al., 1993). This technology is used to modify the grain bulk micro climate and to render it unfavorable for the development of noxious or damaging organisms in the grain, and at the same time to create favorable conditions for the prolong preservation of its quality (Pal and Pandy, 2000). Proper aeration that allows the heat to escape from the paddy mass preserves the quality of the grain. Several researches further indicate that proper storage of paddy in aeration bins can reduce the accumulation of heat in the bin caused by breathing, reduce moisture content. Inhibit microbial growth and slow the yellowing color (Phillips et al.,1988:Ranalli et al., 2003). Storage of seeds at low temperature(cold storage) is in wide spread practice today, and studies have shown that the lower the temperature (within certain limit) the longer the time period for which seeds preserve their quality (Muhlbauer et. al., 1992). The respiration of the rice kernel is difficult to separate from the respiration of molds and other micro flora so it is often measured as one respiration value (Hoseney 1994). As with any cereal grains, rice is subject to deterioration when not properly stored. The major determinants of storage risk are moisture content, temperature, and time of storage (Christensen and Sauer 1982). In a study on the effect of moisture content on milling of rough rice stored for short periods, Mejia-Martinez (1988) observed that rough rice stored at $14 \%$ m.c. over 30 days did not yield discoloured kernels. When stored at $26 \%$ m.c.. rice milled after 5 days of storage had a distinctly creamy colour ( $<1 \%$ of discoloured kernels), and after 10 days had $95 \%$ discoloured kernels. Additionally, he observed that the percentage of kernels yielding fungi decreased drastically at 10 days storage in samples stored at $22 \%$ m.c. and no fungi were recovered from samples at $26 \%$ m.c. The respiration of the rice kernel is difficult to separate from the respiration of melds and other micro flora so it is often measured as one respiration value (Hoseney, 1994). The cooled air is usually reheated by building a small subsidiary condenser into stream of cold air in order to reduce the relative humidity of the air. In general, when grain is exposed to air the air may be gave up moisture to the grain or the grain may release water into the air until the state of equilibrium governed by the vapor pressure of water in the air and the grain is reached. The effects of storage condition on the properties and quality of glutinous rice cultivar RD6 was studied by Wiset et.al. (2011). The storage conditions were cold aeration at 15 and $20 \mathrm{C}^{\circ}$, ambient aeration and storage in gunny bags .Paddy was taken before storage and after 2.4 and 6 months of storage to be determined for the disulfide linkage. Thermal and textural properties including sensory 
evaluation. The results showed that the changes of disulfide linkages in protein were slightly increased with storage periods. Thermal properties were measured by differential scanning calorimetry and found that the enthalpy of gelatinization was the highest in gunny bags storage after 6 months. Cohesiveness and chewiness was increased, while adhesiveness was decreased after storage. Furthermore, the paddy stored at ambient temperature and the paddy stored in the gunny bags had the greatest change in textural properties. Sensory evaluation of cooked rice by trained panellists showed that the paddy stored at ambient temperature and in gunny bags had a yellowing color and abnormal aroma. base on overall acceptance score. Panellists preferred the paddy stored at $15 \mathrm{C}^{\circ}$ and $20 \mathrm{C}^{\circ}$ than that stored in gunny bags(Wiset et al.,2011). Shove (1970) reported that compared to heated air drying, which is done during a short period of a few days. Low temperature grain conditioning can extend over a period of several weeks to a few month's. A longer conditioning period is possible because of grain deterioration. Kawamura et. Al.,(1999) developed a technique for storage rice below ice point using natural coldness of air. Rice storage experiments were carried out at ambient temperature, low temperature (below $15^{\circ} \mathrm{C}$ ) and ice point temperature $\left(-15^{\circ} \mathrm{C}\right)$. The results show that, a combination of rice storage below ice point and natural coldness in winter could be used as a new technique to preserve the rice quality without the need of a cooling unit or electricity. The general objective of the present work is to study and evaluate the aeration of high moisture rough rice as a means of preserving its physical quality during short term storage by using a natural and cooled air.

\section{The specific objectives consist of the following:}

1-To study and evaluate two different types of air (natural and cooled air) used to aeration of high moisture rough rice.;

2-To determine the effect of different air flow rates of the aeration process in lowering the grain bulk temperature as well as reducing the moisture content. and

3- To investigate grain quality changes included grain broken percentage, total milling yield, discoloration and fungal colony count during the aeration process.

\section{MATERIALS AND TEST PROCEDURES}

Rough rice used in this study was of Giza 176 variety which harvested from the experimental farm of Rice Mechanization Center (R.M.C). The initial moisture content of the fresh rough rice was about $25.86 \%$ (w.b) as was determined by pre calibrated Satake moisture meter. Foreign material, broken and un filled grains were removed through winnowing. The prepared samples were stored temporarily in a freezing room adjusted to a temperature of $\left(-5^{\circ} \mathrm{C}\right)$ in order to suppress fungal growth 
and minimize quality changes. Before each experiment the samples were taken out of the freezing room until the temperature of the grain become equal to the ambient temperature. This was to maintain the uniformity of the initial temperature of all samples.

\section{Fabrication Of Storage Bins}

Seven lots of high moisture rough rice each of $(25 \mathrm{~kg})$ were stored under different types of aeration. Three lots stored in insulated steel bins aerated with cooled air. The other four lots were stored in similar size steel bins exposed to the outside environment, three bins were aerated with ambient air and the fourth bin was not aerated and used as control. Each insulated bins was constructed of two concentric circular steel cylinders. The interstice formed between the walls of the two cylinders were filled with pour type insulation (wood sawdust) with thermal conductivity of $0.05 \mathrm{k} . \mathrm{Cal} / \mathrm{h} . \mathrm{m} .{ }^{\circ} \mathrm{C}$.

Two similar centrifugal fans of $0.75 \mathrm{~kW}$ were used for aeration process. Each centrifugal fan furnished air to three bins in both cases of natural and cooled aeration using $10.16 \mathrm{~cm}$ main duct with three branches each branch begin $6.35 \mathrm{~cm}$ diameter. The main ducts as well as each branch were insulated by glass wood for the cooled aeration loins .Each bin was provided with a control valve for air flow rate adjustment based on the required amount of air. The control bin was left without aeration.

Figs. (1 and 2) present an overview of both the normal and the insulated bins used for natural and cooled aeration, respectively.

\section{Cooling unit.}

Cold air for the three insulated bins was obtained from the experimental cooled unit as shown in Fig. (3).

Cooled air was forced through the grain in the three insulated bins at a temperature maintained at approximately 10 to $13{ }^{\circ} \mathrm{C}$. To lower the relative humidity of the cooled air, two parallel condensers were used for the cooling unit as shown in Fig. (4). The relative humidity of the cold air after passing through the evaporator coil was about 38.79 to $43.72 \%$.

\section{Air flow rate adjustment}

Three different air flow rates of $(0.02,0.04$ and 0.06$) \mathrm{m}^{3} / \mathrm{kg}$. h were adjusted by using a K.D.G 200air flow meter model R.A.B 14728 which measure the air flow directly in liter /min. The readings were converted to $\mathrm{m}^{3} / \mathrm{h}$.

\section{Moisture content determination}

Moisture content of rough rice samples of each treatment was measured using a Satake moisture meter. The readings were adjusted subsequently based on the meter calibration against the standard air oven method using $25 \mathrm{~g}$. samples placed in an air oven at $130^{\circ} \mathrm{C}$ for $16 \mathrm{~h}$ as recommended by (AOAC 1990).

\section{Temperature measurement}

The Universal Digital measuring system model UCAM-5PT connected to 36 channel scanning box with thermocouples USB-20A. were used for temperature 
measurement. Copper Constantan thermocouples were placed at the top, middle and bottom centers of each bin for measuring grain bulk temperature. Other thermocouples were used for measuring air temperature at different points of the experimental set-up.

\section{Relative humidity measurement}

The relative humidity meter model $(\mathrm{HN}-\mathrm{K})$ was used to measure air relative humidity at adjacent points of temperature measurements.
A-Test paddy
B-Probe ports
C-Plenum chamber
D-duct

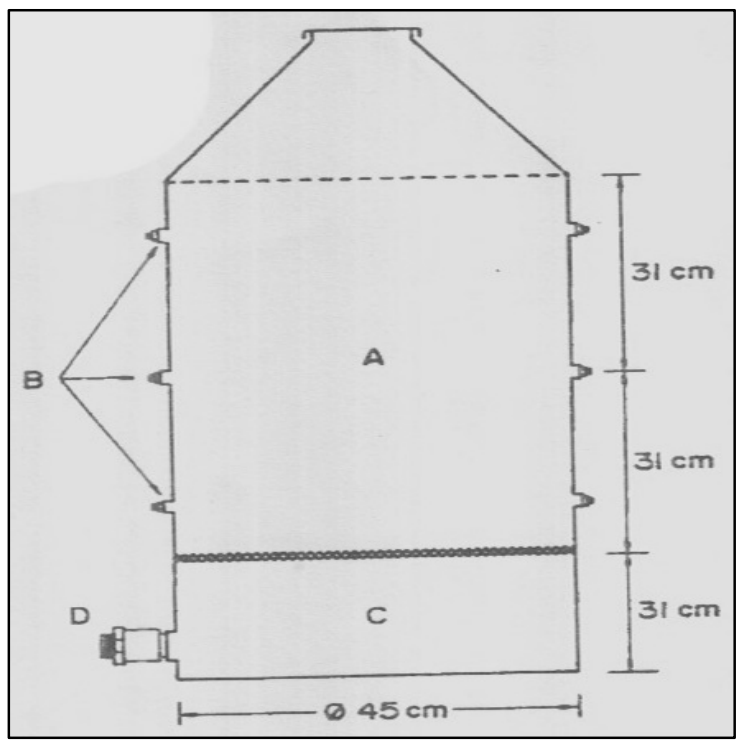

Fig. 1. Over-view of the steel bin used for natural aeration.

A-Test paddy

B-Probe ports

C-Plenum chamber

D-duct

E-Insulation

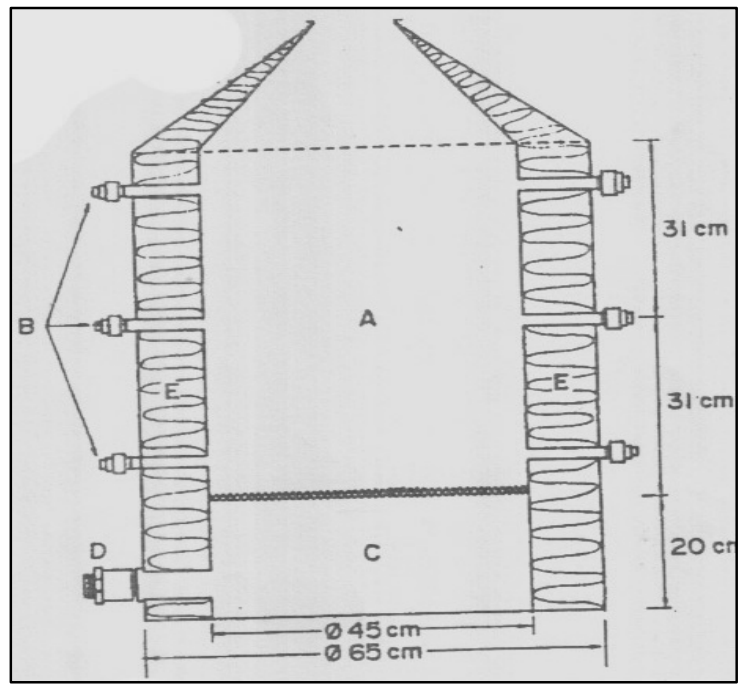

Fig. 2. Over-view of the insulated steel bin used for cooled aeration. 
1- cooled Compressor

2-Filter Dryer

3-Expantion Valve

4-Evaporator Coils

5-Condensers

6-Receiver Tank

7-Control Box

8-Insulation

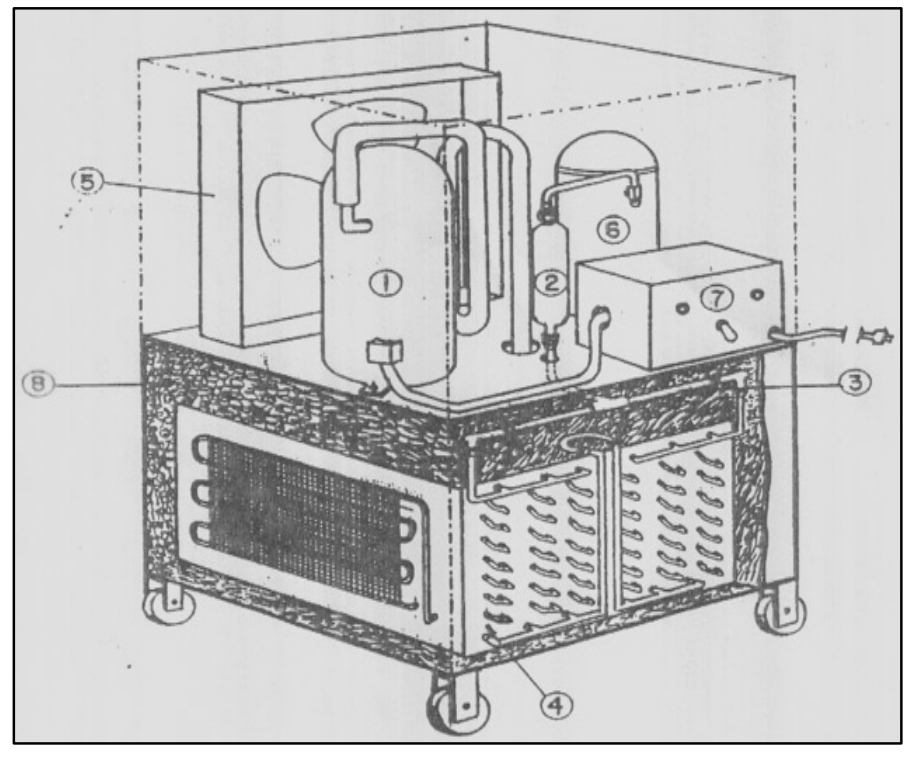

Fig. 3. Overview for the air cooling unit.

1-Fresh Air.

2-Air Cooler.

3-Expantion Valve.

4-Cooled Air Inlet.

5-Blower Fan.

6-Exhaust Air.

7- Condensers.

8-Cooled Air Collector.

9- cooled Compressor. 10-Air Control Valve

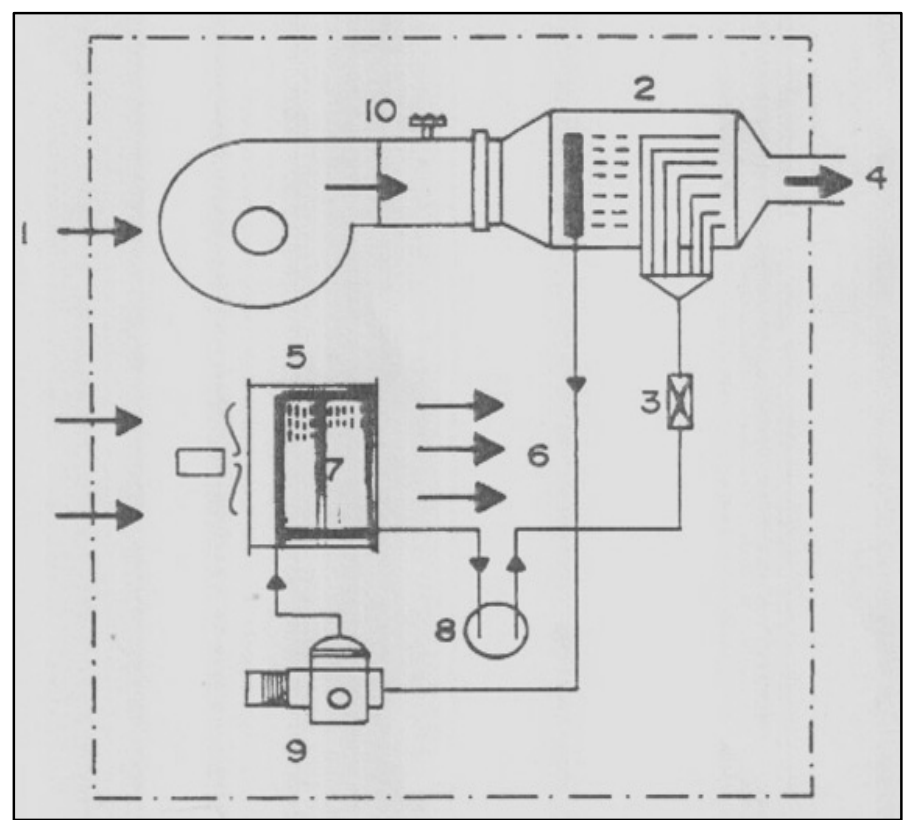

Fig. 4. Schematic diagram for the air cooling unit. 


\section{Fungal colony count.}

The spread plate method recommended by Flannigan (1977) was used to determine fungal colony counts in rough rice samples. Potato dextrose agar (PDA) AT $3.9 \%$ concentration was prepared as a culture medium.

The culture medium was mixed with $10 \%$ tartaric acid to prevent bacterial growth.

\section{Discolored kernel measurement}

A total of $100 \mathrm{~g}$ rough rice samples were dehusked and milled using a "Satake" laboratory mill and polisher. The resulting white rice was weighed and the discolored grains in milled rice were separated manually by visual inspection and then expressed later as a percentage by weight.

\section{Milling Tests}

All rough rice samples were air dried under shade up to $14 \%$ moisture content prior to milling. The milling quality of rough rice samples was evaluated in terms of, percentage of head rice and total milled rice. A Satake rubber roll husker (Model THU 35A) and Satake rice polisher model SKD-DBKK were operated automatically for one minute in each test. For separating head rice from the broken, a laboratory grader Model TRG-05 was used. Percent milled rice recovery, and broken recovery was calculated on the basis of $125 \mathrm{~g}$ sample as follow:

$$
\text { Total rice yield, }(\mathrm{TRY})=\frac{\text { weight of milled rice }(\mathrm{kg})}{\text { Total weight of rough rice sample }(\mathrm{kg})} \times 100
$$

Broken rice yield, $(B R Y)=\frac{\text { weight of broken rice }(\mathrm{kg})}{\text { Total weight of rough rice sample }(\mathrm{kg})} \times 100$

\section{RESULTS AND DISCUSSION}

\section{Grain moisture content}

The average moisture content of grain aerated with natural and refrigerated air using different air flow rates is given in Figs.(5 and 6), respectively.

The results show that grain moisture reduction rate was depended upon air flow rate and type of air used for aeration. For natural aeration, the grain moisture content was reduced from an initial level of $25.83 \%$ to a final levels of $20.1,19.8$, and $19.1 \%$ w.b.to the air flow rates of $0.02,0.04$ and $0.06 \mathrm{~m}^{3} / \mathrm{h} . \mathrm{kg}$, respectively. The corresponded final moisture content for the grain aerated with cooled air were $17.1,16.0$, and $14.7 \%$ w.b., respectively. The observed difference in final grain moisture content of both aeration methods was due to the difference in air flow rates. However when comparing the final moisture content of grain aerated with similar air 
flow rate it was clear that the reduction of moisture content for the grain aerated with natural air was lower than that aerated with cooled air. These results could be attributed to the difference in air relative humidity which was lower for refrigerated air as compared to natural air. In general cooled aeration reduced the grin moisture content to levels sufficient for safe storage of grain without deterioration especially when using 0.04 and $0.06 \mathrm{~m}^{3} / \mathrm{h} . \mathrm{kg}$ air flow rates. Meanwhile, natural aeration still require a combined drying system in order to reach a level of moisture safe for long term storage.

\section{Grain bulk temperature}

The average grain bulk temperature during storage period is given in Figs. ( 7 and 8) for natural and cooled aeration, respectively. As shown in the figures, grain bulk temperature was reduced at higher rates during the early stage of aeration in all treatments and starts to follow different patterns during the proceeded period of storage. The reduction of grain bulk temperature after the first three days of storage for different air flow rates of $0.02,0.04$, and $0.06 \mathrm{~m}^{3} / \mathrm{h}$. $\mathrm{kg}$ were $2.4,3.6$, and $4.1^{\circ} \mathrm{C}$ for natural aeration as compared to $8.7,11.1$ and $13.1{ }^{\circ} \mathrm{C}$ for cooled aeration, respectively. The above mentioned results revealed that, grain bulk temperature was depended upon the temperature of air used for aeration process. For natural air and also the rate of grain moisture reduction which resulted in evaporative cooling of grain. 


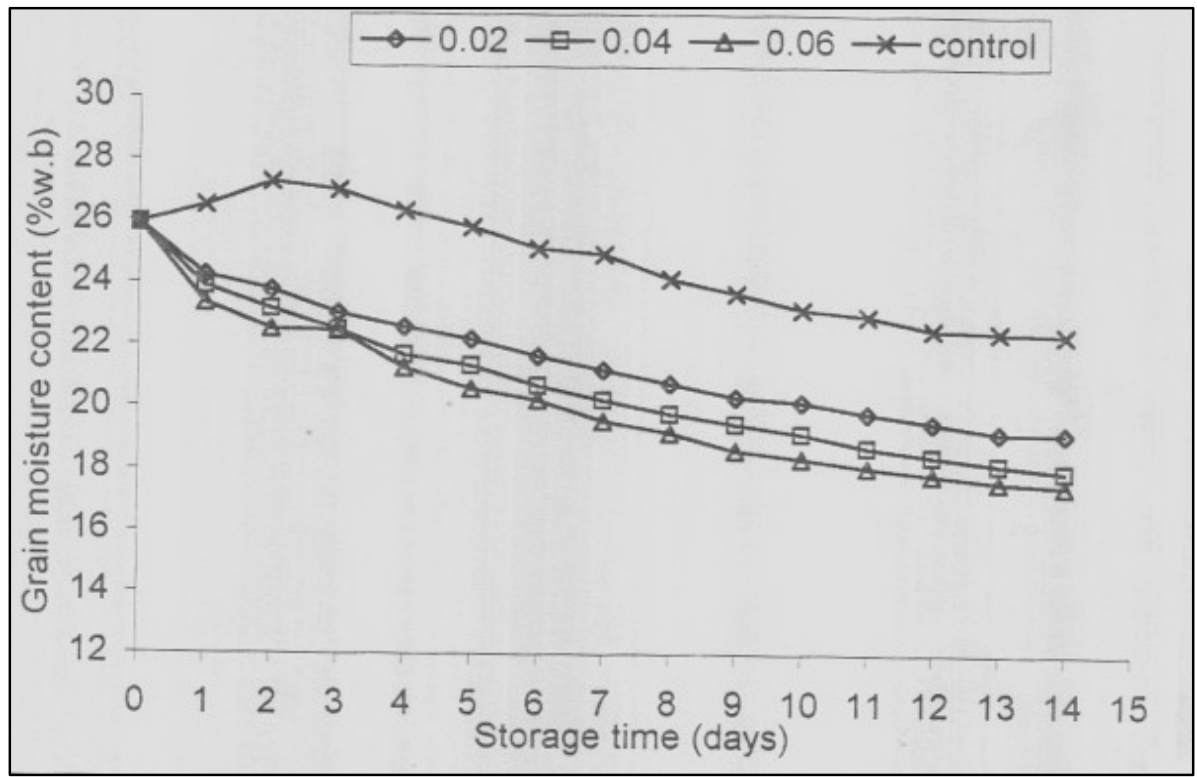

Fig. 5. Change in average moisture content of rough rice aerated with natural air.

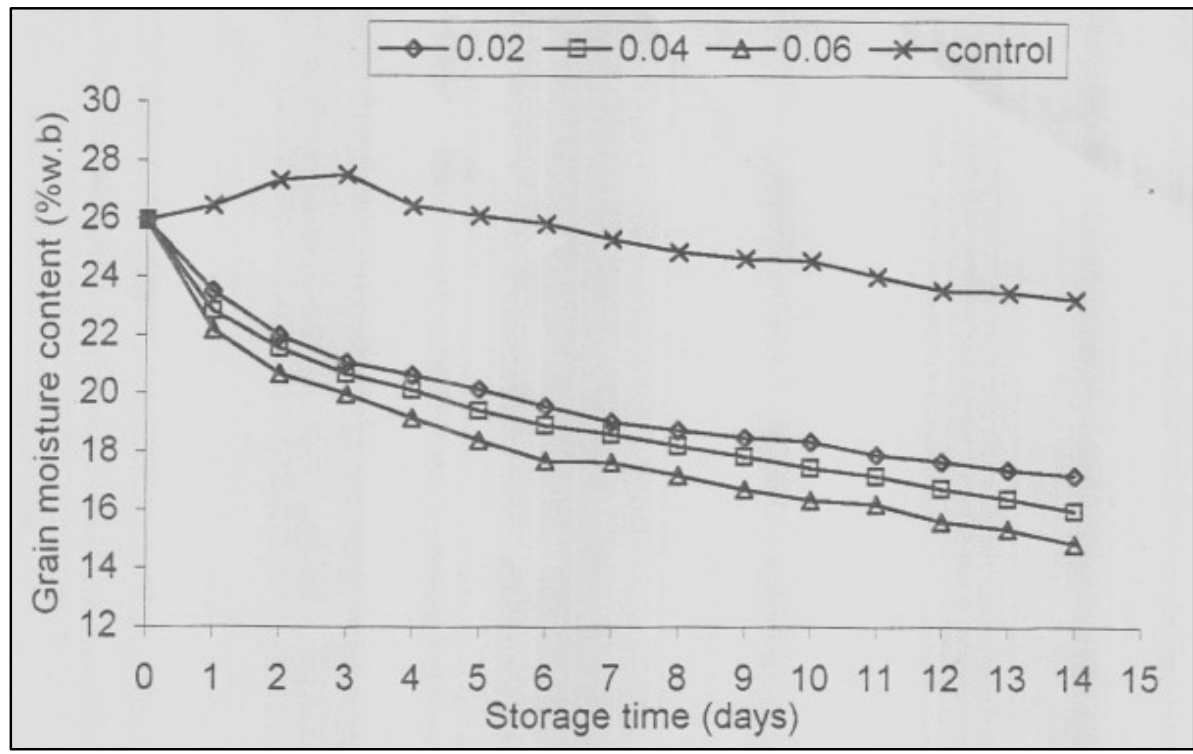

Fig. 6. Change in average moisture content of rough rice aerated with cooled air. 


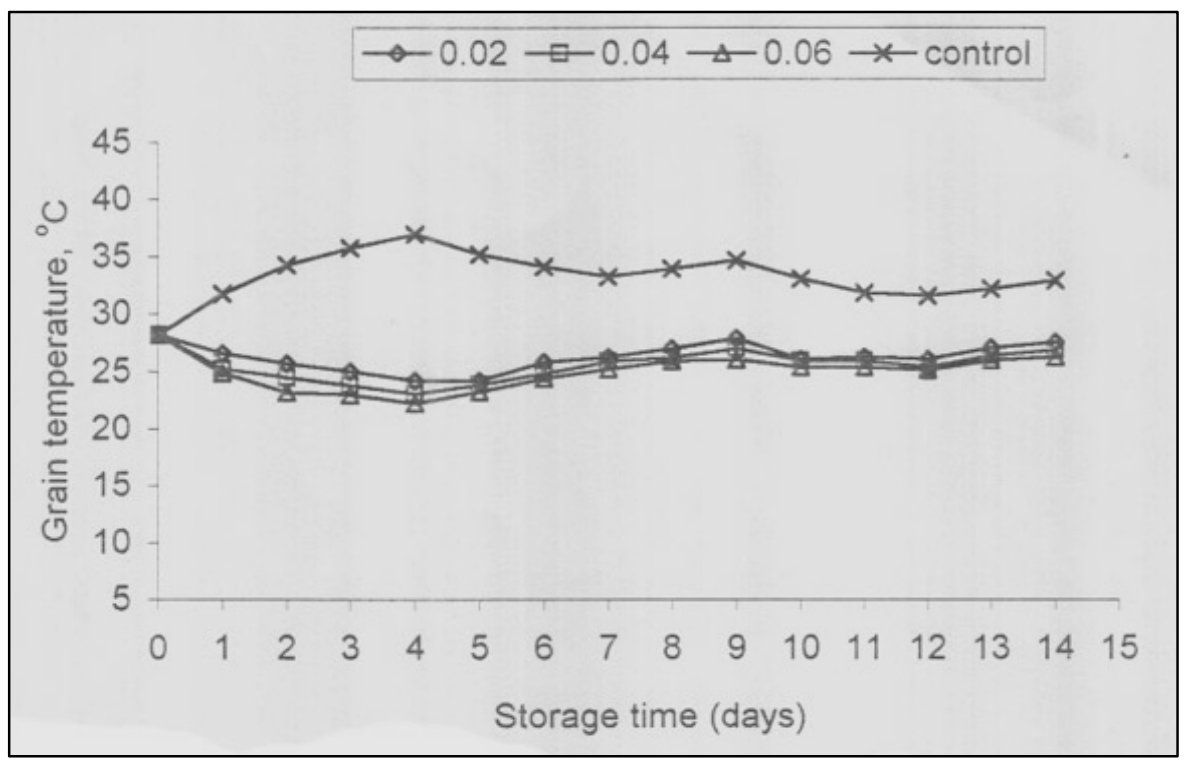

Fig. 7. Change in average bulk temperature of rough rice aerated with natural air.

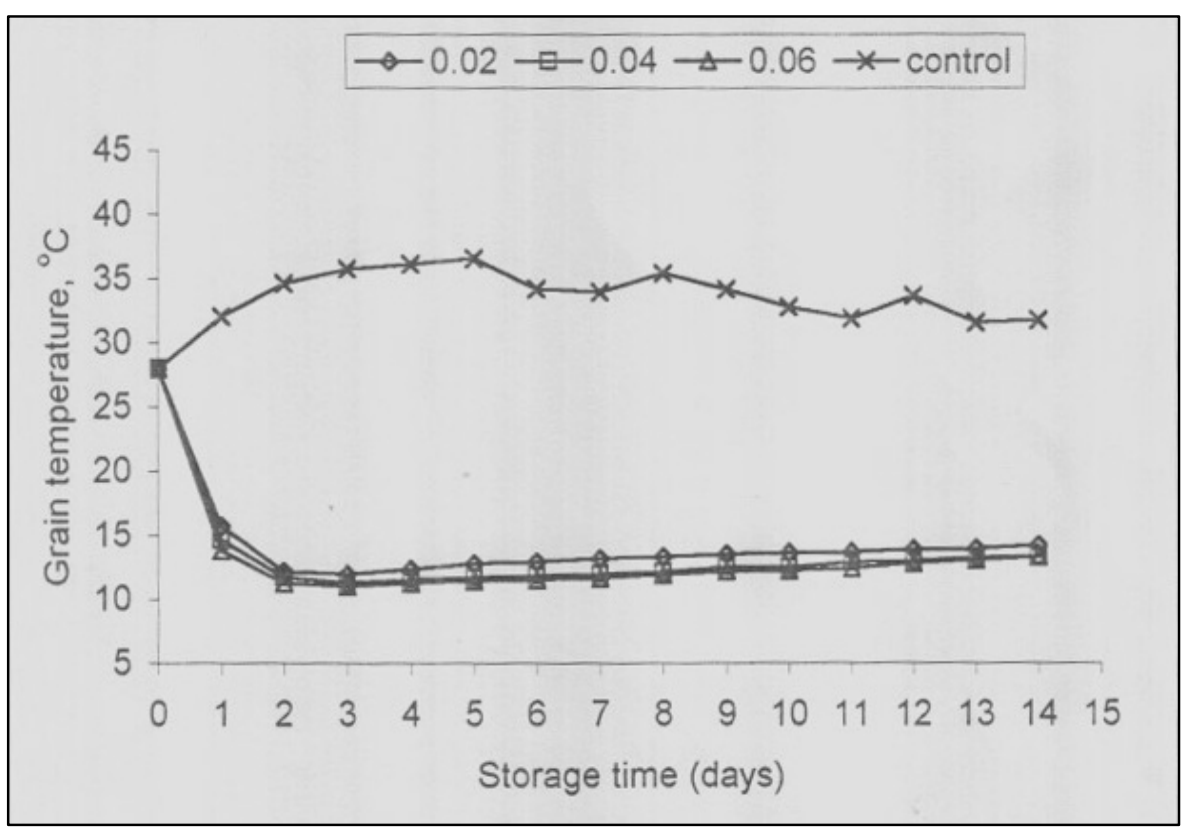

Fig. 8. Change in average bulk temperature of rough rice aerated with cooled air. 
In general, average air temperature ranged from 27.26 to $29.79{ }^{\circ} \mathrm{C}$ with a relative humidity of 68.53 to $76.15 \%$, for the natural aeration process . While, the corresponded temperature and relative humidity for the cooled aeration were (11.1 to $13.92)$ and (38.79 to $43.72 \%)$, respectively.

\section{Fungal growth}

The changes in log fungal count in relation to storage time for grain aerated with natural and cooled air are given in Figs.(9 and 10), respectively. As shown in the figures, rapid growth of fungi was observed during the first three days of storage in both aeration methods. The observed higher rate of fungal growth during this period could be attributed to the higher grain moisture content and temperature. Following this period growth rate of fungi was continued in a lower rate for the grain aerated with natural air and gradually declined for the grain aerated with cooled air. This means that, cooled aeration could suppress fungal growth rate during aeration process as compared to natural aeration.

\section{Grain discoloration}

Laboratory tests for the discoloration of grain aerated with natural and cooled air are presented in Fig. (11). Higher percentages of discoloration was observed at the treatments aerated with natural air as compared to cooled air. The observed higher percentage of grain discoloration in natural aerated treatments could be attributed to the action of fungi metabolisms on pigments within the rice bran and/or by pigments synthesized by mold themselves when grain moisture content and temperature is favorable for fungal growth as reported by (Jindal and Reyes 1987).

\section{Milling quality}

Laboratory milling tests, were conducted for representative samples of grain before and after aeration process. The results of laboratory analysis on milling quality of grain aeration with natural and cooled air are given in Fig.(12). As shown in the figure, a higher milling recovery was observed for the treatments aerated with cooled air in compression with natural air.

When comparing the broken rice of different treatments at the end of storage period, it was obvious that percent broken rice was greatly lower for the treatments aerated with cooled air as compared to natural air. 


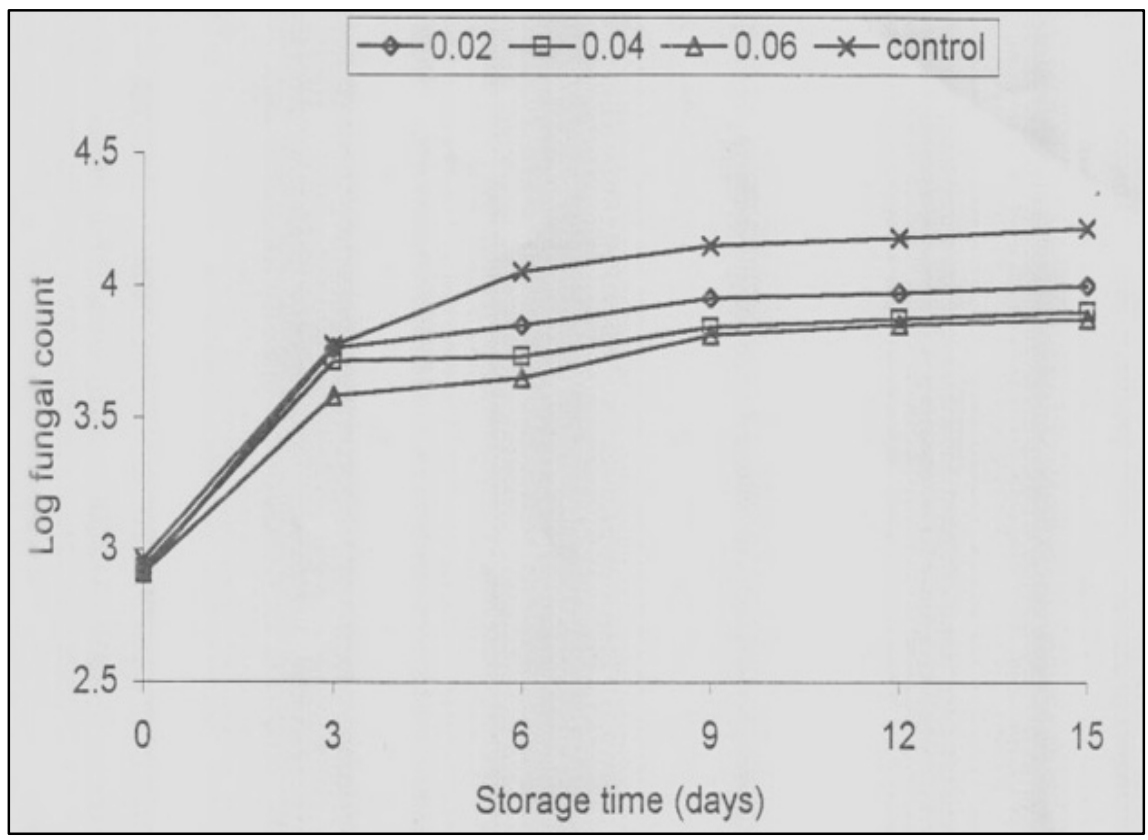

Fig. 9. Fungal colony count in rough rice aerated with natural air.

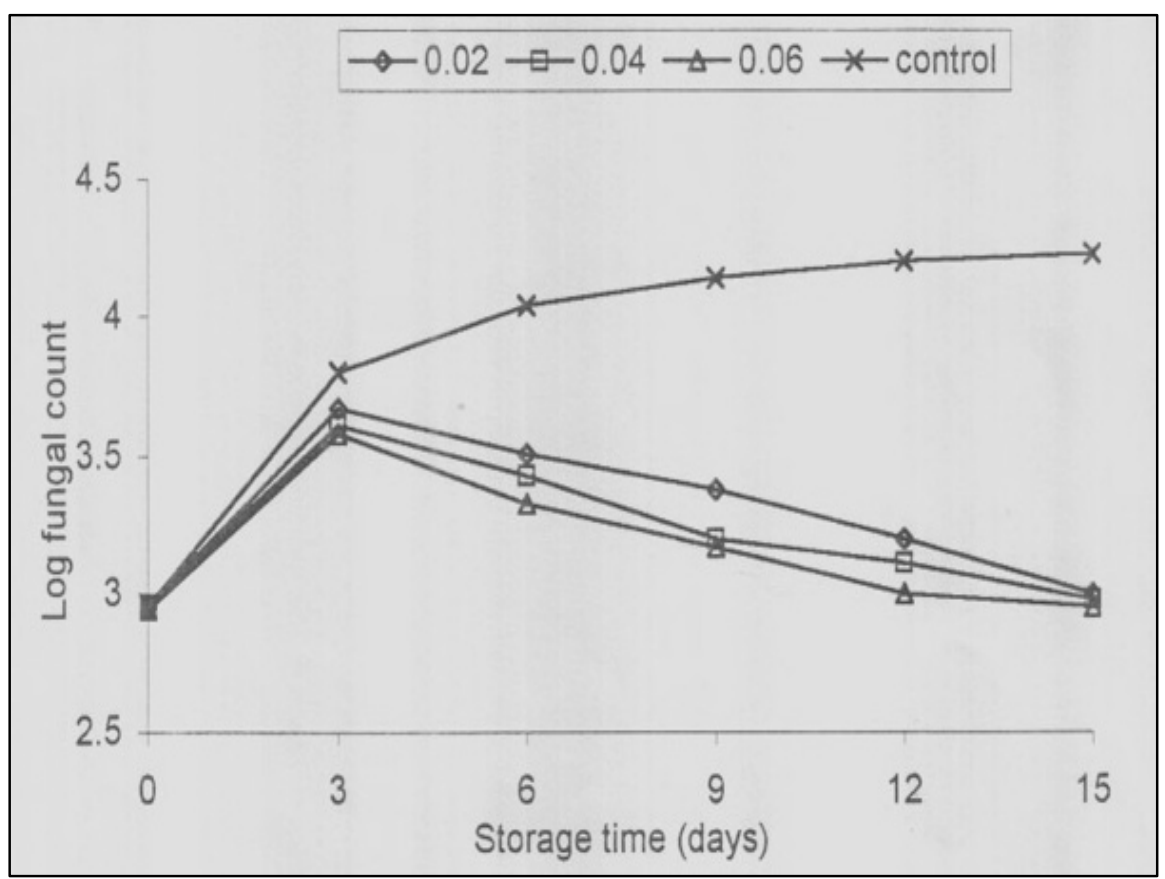

Fig.10. Fungal colony count in rough rice aerated with cooled air. 


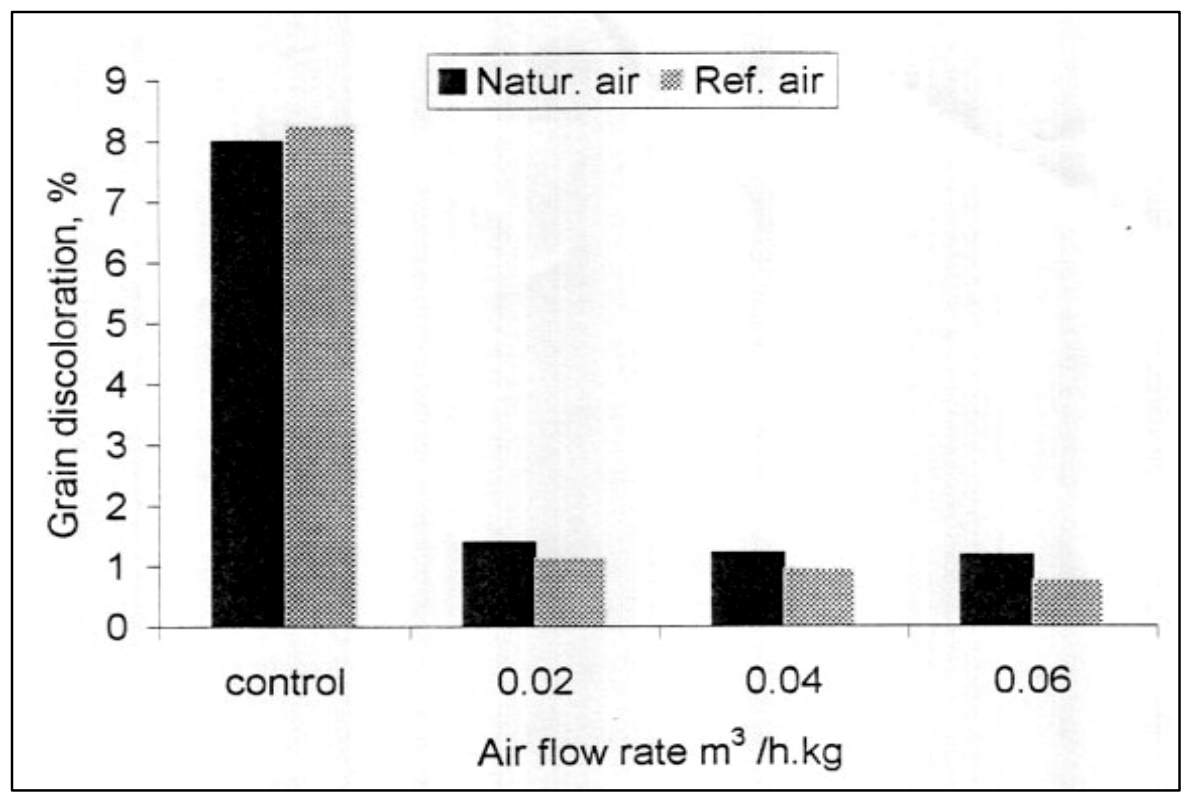

Fig. 11. Percent discoloration of rough rice aerated with natural and cooled air.

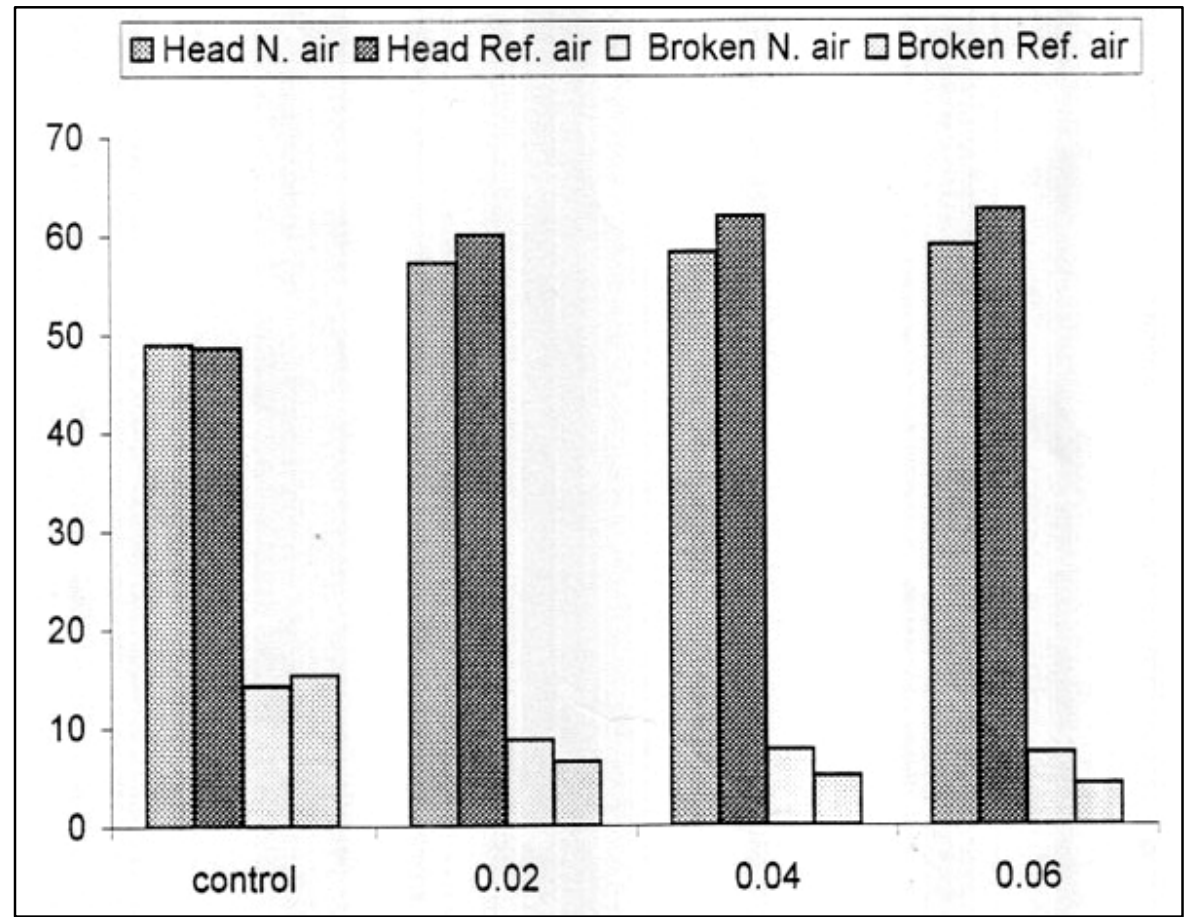

Fig. 12. Milling test of rough rice aerated with natural and cooled air. 
The percent improvement in milling quality was assessed for the treatments aerated with cooled air as compared to natural air, the results are shown in Table (1). It was clear that aeration with cooled air improved the milling quality of grain at the end of storage period, as compared to natural air. The present improvement in rice milling quality was ranged from (0.9-1.17\%) for milled rice recovery and from (25.54$42.95 \%)$ for broken rice recovery.

Table 1 . Milling quality of paddy aerated with natural and cooled air.

\begin{tabular}{|c|c|c|c|c|c|}
\hline $\begin{array}{c}\text { Milling } \\
\text { quality }\end{array}$ & $\begin{array}{c}\text { Air flow rate } \\
\mathrm{m} 3 / \mathrm{h} . \mathrm{kg}\end{array}$ & $\begin{array}{c}\text { Natural air } \\
(1)\end{array}$ & $\begin{array}{c}\text { Cooled air } \\
(2)\end{array}$ & $\begin{array}{c}\text { Difference(3) } \\
=(2)-(1)\end{array}$ & $\begin{array}{c}\text { \%improvement (4) } \\
=(3 / 1) * 100\end{array}$ \\
\hline Milled rice & Control & 63.19 & 63.97 & - & - \\
recovery (\%) & 0.02 & 65.96 & 66.65 & +0.6 & +0.9 \\
& 0.04 & 66.27 & 66.98 & +0.71 & +1.07 \\
& 0.06 & 66.34 & 67.12 & +0.78 & +1.17 \\
\hline \multirow{2}{*}{ Broken rice } & Control & 14.27 & 15.36 & - & - \\
$(\%)$ & 0.02 & 8.69 & 6.47 & $(-) 2.22$ & $(-) 25.54$ \\
& 0.04 & 7.95 & 5.17 & $(-) 2.78$ & $(-) 34.96$ \\
& 0.06 & 7.31 & 4.17 & $(-) 3.14$ & $(-) 42.95$ \\
\hline
\end{tabular}

\section{CONCLUSION}

1- Grain moisture reduction rate was higher for the treatments aerated with cooled dry air as compared to natural air. The rate of moisture reduction was depended upon air flow rate in both methods of aeration.

2- The dry and cooled air used for cooled aeration results in higher temperature reduction as compared to natural air.

3- Aeration with cooled air reduced fungal growth rate percent discolored kernels, and broken percentage of milled rice as compared to natural air.

\section{REFERENCES}

1. AOAC. 1990. Official Methods of Analysis ( $15^{\text {th }} \mathrm{Ed}$ ), Association of Official Analytical Chemists, Washington DC.

2. Chang C.S., H.H Converse and J.L. Steel. 1993. Modeling of temperature of grain during storage with aeration. ASAE 36(2):509-519.

3. Christensen, C. M. and D. B. Sauer. 1982. Microflra. In Christensen, C.M., ed., Storage of cereal grains and their products. St Paul, Minnesota, American Association of Cereal Chemists Inc, 219-240. 
4. Flannigan B. 1977. Enumeration of fungi and assy for ability to degrade structural and storage components of grain. In Biodeterioration Investigation Techniques Applied Sience Pub.Ltd., London.:185-199.

5. Hoseney, R. C. 1994. Principles of Cereal Science and Technology. Am. Assoc. Cereal Chem.: S. Paul, MN.

6. Hoseney, R.C. 1994. Principles of Cereal Science and Technology. Am. Asoc. Cereal Chem .:St. Paul, MN.

7. Jindal, V.K.; and V.G. Reyes. 1987. Conduction heating of rough rice for accelerated drying. Paper No.87-6043,ASAE, Summer Meeting Baltimore, June 28-July,ASAE st. Joseph, MI.

8. Kawamura S.K.; T. Ogawa and K. Itoh. 1999. Rice storage below ice point using natural coldness to preserve its quality. Paper presented at the Annual International Meeting of ASAE Paper No.996044 ASAE, Josepl St. U.S.A.

9. Mejia-Martinez, F. 1988. Effect of moisture content on milling of rough rice stored for short periods of time. M.S. Thesis. Kansas State Univ. :65.

10. Muhlbauer W.; G.Maier; T. Tberggo, A. Esper ; G. R. Quick; and F. Mazaredo. 1992. Low temperature drying of Paddy under humid tropical condition, AMA23 (4): 33-41.

11. Pal. V. and J. Pandey. 2000. Effect of storage on rice yield recovery. Journal of Food Science and Technology. Mysore 37: (4), PP.427-429.

12. Phillips S., S., Widjaja, A. Wallibridge, R. Cooke. 1988. Rice yellowing during postharvest drying by aeration and during storage. J Stored prod Res24:173-181.

13. Ranalli R.P., T.A. howell, T.J Siebenmorgen. 2003. Effects of controlled ambient aeration on rice quality during on- farn storage. Cereal Chem 80:9-12

14. Shove G. C. 1970 . Potential energy use in low temperature grain conditioning. Trans. of The ASAE 13 (1): 58-60.

15. Wiset, P. Laoprasert, C. Borompichaichartkul, N. Poomsa-ad and V. Tulyathan. 2011. Effects of in-bin aeration storage on physicochemical properties and quality of glutinous rice cultivar RD 6. AJCS5(6):635-640.

16. Zhou Z., K., Robards, S. Helliwel and C. Blanchard. 2002. Ageing of stored rice: changes in chemical and physical attributes. J Cereal Sci 35:65-78. 


\title{
تهوية حبوب الأرز ذو المحتوى الرطوبى المرتفع باستخدام الهواء الطبيعى والمبرد
}

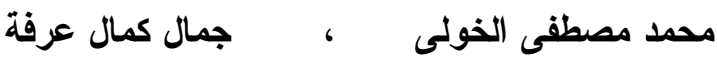 \\ معهُ بحوث الهندسة الزراعية - مركز البحوث الزراعية - الدقى - الجيزة - مصر
}

نتيجة لانتشار استخدام نظام الحصاد الميكانيكى بالكومباين بعد حصاد حبوب الأرز عند

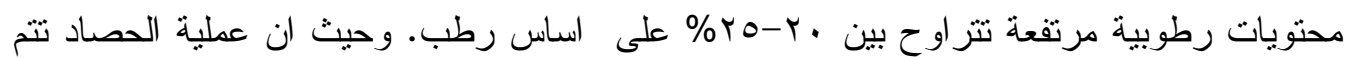
لكميات كبيرة من المحصول فى فترة زمنية قصيرة مع عدم وجود الامكانيات اللازمة لتجفيف تلك

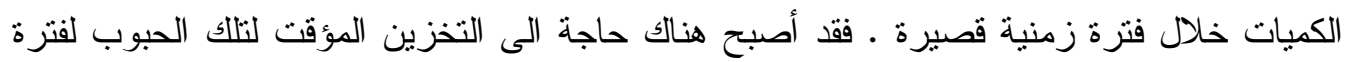

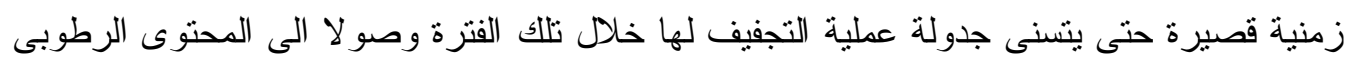
الآمن لعملية التخزين طويل المدى من هنا أجريت تلاك الدراسة لتقييم تأثثر التهوية الميكانيكية

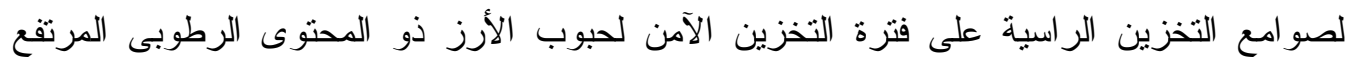

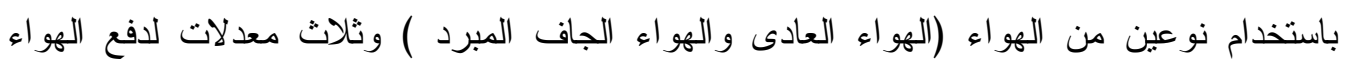

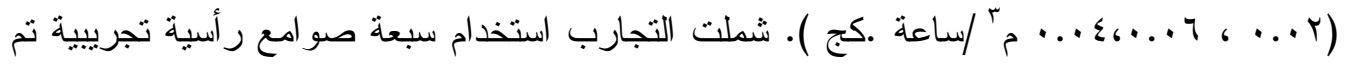

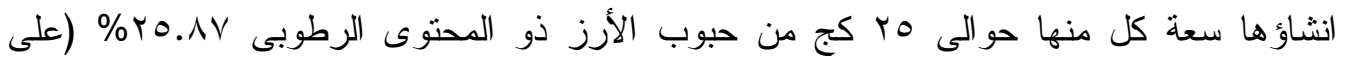
الأساس الرطب).

وقد تمت عملية التهوية لنلاث صوامع منها باستخدام الهواء العادى كما استخدم الهواء

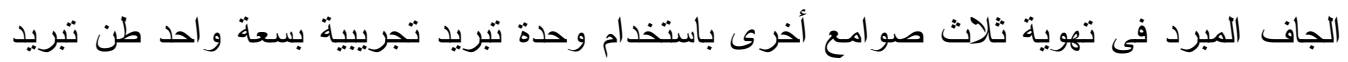

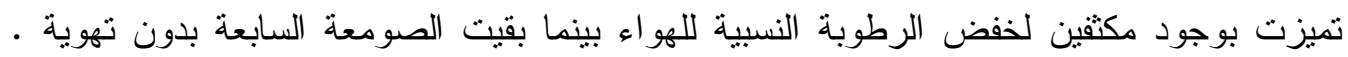

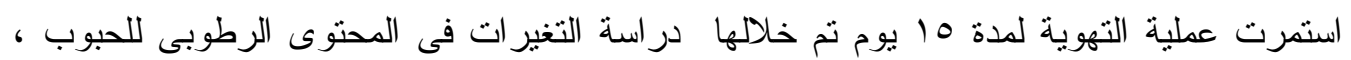

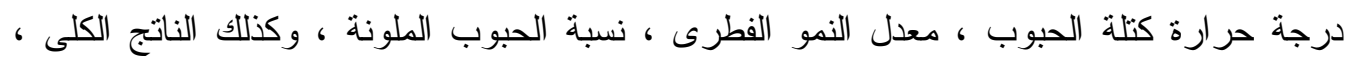

$$
\begin{aligned}
& \text { جودة الضرب ونسبة الكسر فى الحبوب . } \\
& \text { أظهرت نتائج التجارب مايلى }
\end{aligned}
$$

1- تأثر معدل فقد الرطوبة فى الحبوب المخزنة بكلا من نوعية الهواء المستخدم ومعدل دفع الهو اء

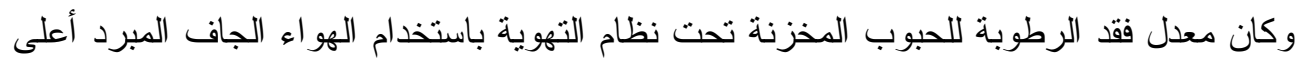

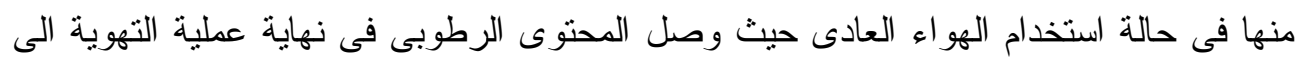

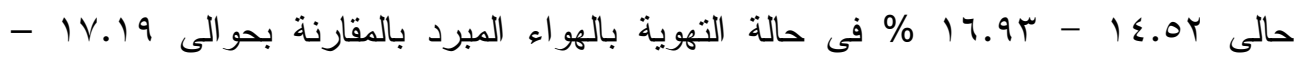

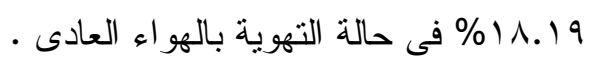

r- انخفضت درجة حرارة كتلة الحبوب المخزنة تحت نظام التهوية باستخدام الهواء الجاف المبرد

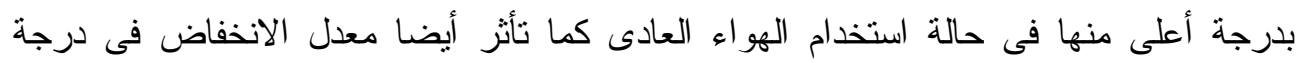

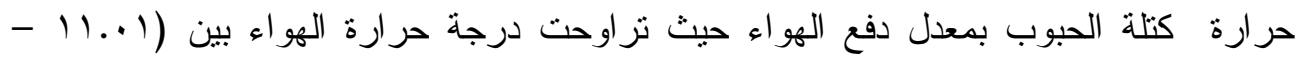

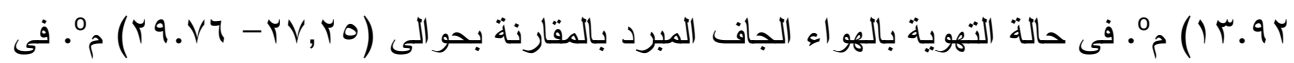

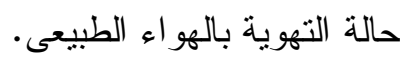
r- أدت التهوية الميكانيكية للحبوب باستخدام الهو اء الجاف المبرد الى انخفاض معدل النمو الفطرى، نسبة الحبوب الملونة وكذلك نسبة الكسر فى الحبوب بالمقارنة بالحبوب التى تم تهويتها باستخدام

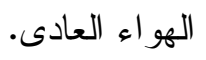

